\title{
SOCIO-DEMOGRAPHIC DETERMINANTS OF LEISURE TIME PHYSICAL INACTIVITY OF ADOLESCENTS FrOM THE VOIVODESHIPS OF CENTRAL POLAND
}

\author{
Elżbieta Biernat, ${ }^{1, A, C, D}$ Adrian Lubowiecki-Vikuk ${ }^{2, A, B, D, E}$ \\ ${ }^{1}$ Department of Tourism, Warsaw School of Economics, Warsaw, Poland \\ ${ }^{2}$ Faculty of Physical Culture, Health and Tourism, Kazimierz Wielki University, Bydgoszcz, Poland \\ ${ }^{\text {A }}$ Study Design; ${ }^{\mathrm{B}}$ Data Collection; ${ }^{\mathrm{C}}$ Statistical Analysis; ${ }^{\mathrm{D}}$ Manuscript Preparation; E Funds Collection \\ Address for corpespondence: \\ Adrian Lubowiecki-Vikuk \\ Kazimierz Wielki University, Faculty of Physical Culture, Health and Tourism \\ Mińska 15, Bydgoszcz, Poland \\ Email: lubowiecki@ukw.edu.pl
}

\begin{abstract}
Ahstract The aim of the study is to assess the physical leisure time activity among the students of grade I-III of junior high school (aged 13-16) - during the school year and holidays - and identify possible causal factors of physical inactivity in this social group. The relationship between participation in sport for all during the school year (regular, periodic, sporadic) and during holidays (physically active/passive) and socio-demographic variables characterizing the structure was analyzed using the $\mathrm{Chi}^{2}$ test. The relationship between respondents inactivity and those traits was assessed using log-linear analysis. The higher the grade (especially among girls), the more physically inactive individuals, the number of which grew during the school year as well as during holidays. The risk factors for inactivity included high BMI, living in the countryside and female sex. In case of girls (76.3\%) the risk of inactivity increased by almost 1.4 times, as it did $(\mathrm{OR}=0.75)$ with regard to living in rural areas $(76.4 \%)$. The chance of being active increases more than 3 -fold among those with normal BMI $(28.0 \%)$ and the underweight $(29.9 \%)$. Adolescents' inactivity (increasing along with the grade pupils are in) points to the shortcomings of Polish process of education and an urgent need for system-based approach to promote active lifestyle in this social group.
\end{abstract}

Key worlls adolescent, leisure activities, sedentary lifestyle, physical activity, social determinants of health

\section{Introduction}

Numerous connections between physical activity and health clearly indicate that in the current civilization the concern about physical condition is a duty and an integral part of the rhythm of life of a modern man (Vuori, 2004; Lee et al., 2012). Despite generally known recommendations, almost half of young Europeans do not undertake the recommended dose of physical activity (EU Physical Activity Guidelines, 2008).

Global organizations concerned about huge losses borne by society as a result of increasing hypokinesis and low level of physical aptitude - especially among young people - are calling for the promotion of healthenhancing physical activity as essential to modern public health strategies. Due to the extent of the problem - more 
important than the other, the individual risk factors of non-communicable diseases - are mobilizing research centers in the world to do cross-sectional research of physical activity (Soos et al., 2012; Parvizi, Hamzehgardeshi, 2014; Soos et al., 2014; Sterdt et al., 2014; Wang et al., 2014). Forming positive habits of spending free time, ways of recharging vitality and active recreation requires not only knowledge of the consequences of their absence, but also familiarity with the current level of physical activity of the young generation and the factors determining it, but also the awareness of factors determining this inactivity and the knowledge of current level of physical activity of young generation (Trang et al., 2009; Dias et al., 2015; Lo et al., 2015). Its assessment is the starting point of action of the environments activating children and school students and pro-health policy-makers.

The aim of study is to assess the physical leisure time activity among the students of grade I-III of junior high school (aged 13-16) - during the school year and holidays - and identify possible causal factors of physical inactivity in this social group. It was assumed that the objective of the research will require answers to two research questions: 1) what is the frequency (regular, periodic, sporadic) of taking recreational physical activity among junior high school pupils outside school? and 2) how (actively /passively) junior high school pupils spend their holidays? Given that, the authors hypothesised that the lack of participation of junior high school students in sport for all is significantly associated with specific socio-demographic determinants, especially the stage of education.

\section{Material and methods}

The study included a representative (random-intentional) group of 1,067 junior high school students (the assumed error is $3 \%$; typical choice is $95 \%$ ) of the selected voivodeships in Poland (Masovia, Lodz Voivodeship, Greater Poland, Cuiavia and Pomerania, Warmia and Masuria).

The sampling frame was Central Statistical Office Local Data Bank collections, which showed that in Poland the number of junior high school for children and adolescents (excluding special schools and for adults) was in the school year 2012/2013 over 1.1 million (1,133.709). Pupils socio-cultural diversity along with lower capital intensity and greater availability and acceptance of schools authorities to do this kind of research contributed to the choice of this part of Poland region as an area of exploration. The study was conducted at the end of the summer season, i.e. September and early October 2013.

In order to select the test group a two-stage draw system was applied. The first stage consisted of random selection among all junior high school located in central Poland, covering two spatial layers: towns and rural areas. Then, in each school, one class of a given grade (first, second, third) was deliberately chosen, where research included all pupils present that day in geography class.

A questionnaire survey was used as a research tool and a standardized interview was conducted by trained interviewers. In the questionnaire there were two closed questions and respondents' particulars. The author's own survey (modified after a pilot version) included questions on participation in sport for all (except for mandatory physical education classes) over the last year. Sport for all was defined as "all forms of physical activity which, through casual or organized participation, aim at expressing or improving physical fitness and mental well-being, forming social relationships or obtaining results in competition at all levels" (European Sports Charter, 1992). The respondents were asked about the frequency of undertaking these forms of physical activity during the school year. Regular participation meant sport for all at least once per week, periodic - a few or more days in a row, several times per season, sporadic - a few times a year. Questions were also asked about the way of spending holidays (active/passive). Spending holidays in an active way meant the respondents participation in individual or 
organized recreational activities in their permanent place or residence and during tourist trip. Inactive (passive) way of spending holiday involved staying in permanent place of residence (tourist inactivity) and choosing passive forms of spending free time, such as: watching TV programmes, using a computer, reading books, etc. Taking into account respondents answers concerning recreational physical activity during school year and during holiday, two groups were distinguished - physically active and inactive respondents.

- physically active (regularly undertaking sport for all during school year and at the same time actively spending their holidays),

- physically inactive (periodically or occasionally taking up a sport for all during school year and physically inactive during the holiday season).

Table 1. Characteristics of the researched group of junior high school students $(n=1,067)$

\begin{tabular}{|c|c|c|c|c|c|c|}
\hline \multirow{2}{*}{ Variables } & \multicolumn{2}{|c|}{ Boys } & \multicolumn{2}{|c|}{ Girls } & \multicolumn{2}{|c|}{ Total } \\
\hline & $\mathrm{n}$ & $\%$ & $\mathrm{n}$ & $\%$ & $n$ & $\%$ \\
\hline \multicolumn{7}{|c|}{ Grade } \\
\hline I (13/14 years old $)$ & 226 & 44.8 & 209 & 37.2 & 435 & 40.8 \\
\hline II (14/15 years old) & 130 & 25.7 & 160 & 28.5 & 290 & 27.2 \\
\hline III (15/16 years old) & 149 & 29.5 & 193 & 34.3 & 342 & 32.1 \\
\hline \multicolumn{7}{|c|}{ Place of residence } \\
\hline Town & 279 & 55.2 & 280 & 49.8 & 559 & 52.4 \\
\hline Rural area & 226 & 44.8 & 282 & 50.2 & 508 & 47.6 \\
\hline \multicolumn{7}{|c|}{ Voivodeships } \\
\hline Cuiavian-Pomerania & 355 & 70.3 & 369 & 65.7 & 724 & 67.9 \\
\hline Warmian-Mazurian & 49 & 9.7 & 71 & 12.6 & 120 & 11.2 \\
\hline Greater Poland & 31 & 6.1 & 28 & 5.0 & 59 & 5.5 \\
\hline Łódź & 38 & 7.5 & 45 & 8.0 & 83 & 7.8 \\
\hline Masovian & 32 & 6.3 & 49 & 8.7 & 81 & 7.6 \\
\hline \multicolumn{7}{|c|}{ BMI } \\
\hline Underweight & 151 & 32.2 & 183 & 36.5 & 334 & 34.4 \\
\hline Norm & 283 & 61.8 & 310 & 60.3 & 593 & 61.1 \\
\hline Overweight/obesity & 35 & 7.5 & 9 & 1.8 & 44 & 4.5 \\
\hline
\end{tabular}

In addition to information on participation in sport for all, interviewers collected data on sex, year of birth, grade (level of education), place of residence and the height and weight of respondents (Table 1).

The relationships between participation in sport for all (regular, periodic, sporadic) during the school year and holidays (physically active/passive) and socio-demographic variables characterizing the structure of junior high school students (sex and level of education) was determined using a $\mathrm{Chi}^{2}$ test. The relationships between respondents inactivity and variables characterizing the demographic structure (sex, level of education, BMI, place of residence, voivodeships) were assessed using a $\mathrm{Chi}^{2}$ test. The results are shown using fractions, and the odds ratios and $95 \%$ confidence intervals. Analyses were made using the statistical package IBM SPSS version 21. In assessing the significance of the effects, the assumed level of significance was $p \leq 0.05$. 


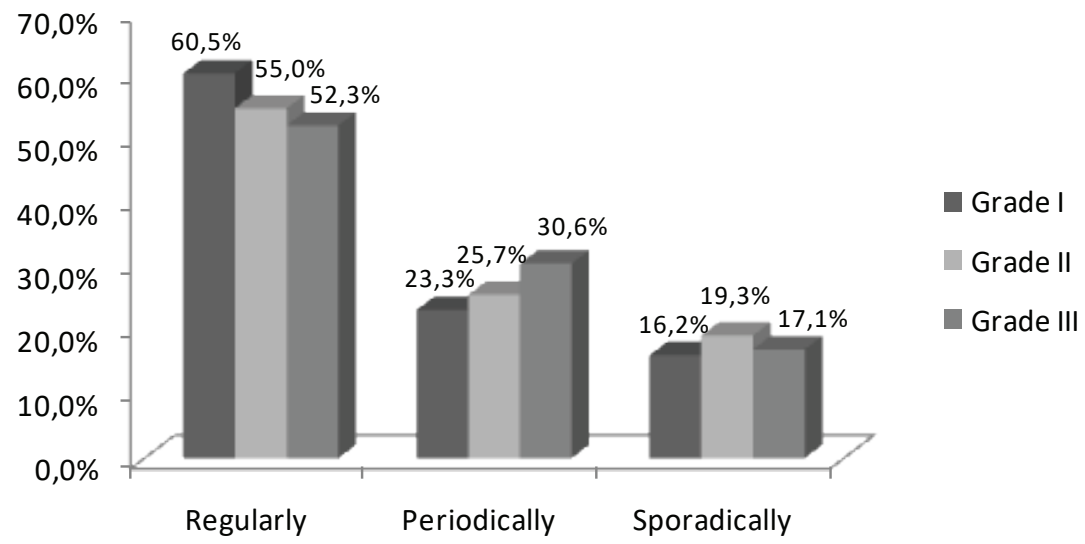

Figure 1. Participation in sport for all (regular, periodic, sporadic) junior high school students depending on the level of education

\section{Resulls}

Sport for all as it is widely and universally understood was undertaken by $95.7 \%$ of the researched junior high school students (equally frequently by the $1^{\text {st }}$ graders $-93.8 \%$, the $2^{\text {nd }}$ graders $-96.6 \%$, as well as the third grade pupils $-97.4 \%$ ). At the same time, regular participation was reported by $56.3 \%$ of them $-26.3 \%$, and the occasional $-17.3 \%$. $\mathrm{Chi}^{2}$ test analysis revealed no significant differences in the nature of this participation (regular, periodic, sporadic) depending on the level of education (Figure 1). However, it was noted that with the transition to a higher grade, the fraction of regularly active pupils decreased $\left(1{ }^{\text {st }}\right.$ grade $-60.5 \%, 2^{\text {nd }}$ grade $-55.0 \%, 3^{\text {rd }}$ grade $\left.-52.3 \%\right)$, and periodically active - increased (respectively $23.3 \%, 25.7 \%$ and $30.6 \%$ ).

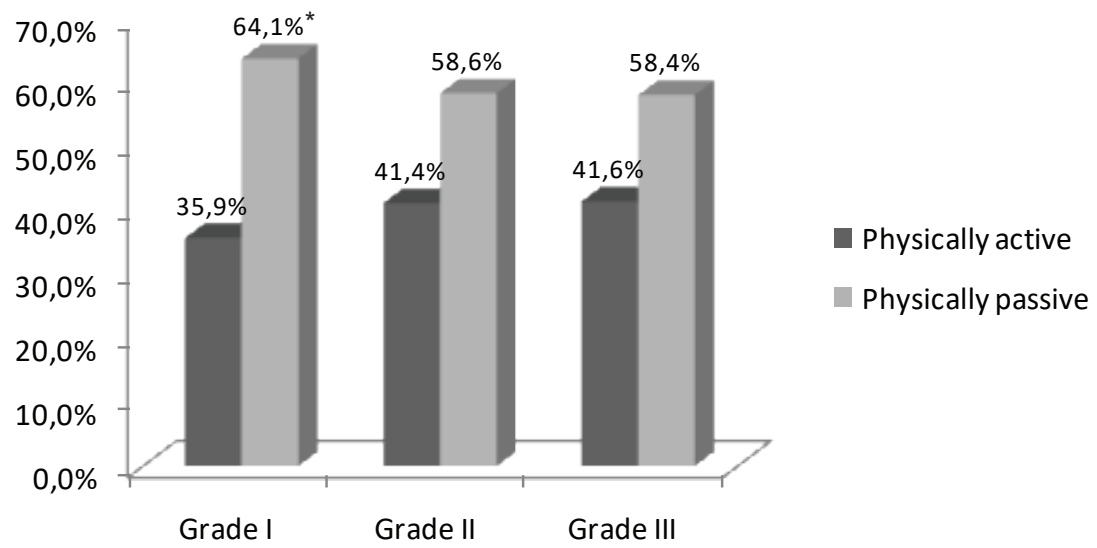

${ }^{*}$ significantly different from physically active $(p \leq 0.001)$.

Figure 2. The way of spending holidays (physically active/passive) for junior high school students depending on their level of education 
Similarly, there was no statistical relationship between passive and physically active holiday and the level of education (Figure 2). Unfortunately, the percentage of pupils inactive during a holiday - regardless of age - was much higher than the active ones (Grade II. -58.6 vs. $41.4 \%$; Grade III. -58.6 vs. $41.6 \%$ ). Statistical differences - but only at the level of $p \leq 0.001\left(\mathrm{Chi}^{2}=3.48, \mathrm{df}=2 ; \mathrm{p} \leq 0.001\right)$ - were noted in this regard only in case of first graders who declared an active holiday (35.9\%) less frequently than the passive one (64.1\%).

Gender was a factor that had a significant relationship $\left(\mathrm{Chi}^{2}=13.30, \mathrm{df}=2 ; \mathrm{p} \leq 0.05\right)$ with undertaking sport for all. Regardless of the grade of junior high school they were in boys often declared a regular character of undertaken physical activity (62.3\%) than girls (50.9\%) (Table 2). These differences were particularly evident in the third grade (boys $-63.0 \%$; girls $-43.9 \%$ ). Meanwhile, third grade girls more often than their male counterparts $(23.3 \%$ ) practiced sport regularly $(36.4 \%)$.

The analysis of the group of boys and girls (only) showed that among the first - regardless of their level of education - there was no significant difference in making sport for all (regular, periodic, sporadic). In the group of girls, however, the relationship was significant $\left(\mathrm{Chi}^{2}=11.41, \mathrm{df}=4 ; \mathrm{p} \leq 0.05\right)$. The girls of the first class more often than other female secondary school pupils practice various forms of sport regularly (58.5\%), and grade III vice versa - periodically (36.4\%).

In examining the determinants of physical inactivity respondents were taken into account the variables presented in Table 3 junior high school students were classified as physically active people (regularly undertaking sport for all and at the same time actively spending holidays) and inactive (other).

Table 2. The participation of junior high school students in sport for all (regular, periodic, sporadic) during the school year and during the holiday season (active/passive)

\begin{tabular}{|c|c|c|c|c|c|c|c|c|c|c|c|c|c|c|c|c|c|}
\hline \multirow{3}{*}{ Factors } & & \multicolumn{4}{|c|}{ Grade I } & \multicolumn{4}{|c|}{ Grade II } & \multicolumn{4}{|c|}{ Grade III } & \multicolumn{4}{|c|}{ Total } \\
\hline & & \multicolumn{2}{|c|}{$\begin{array}{c}\text { Boys } \\
(n=226)\end{array}$} & \multicolumn{2}{|c|}{$\begin{array}{c}\text { Girls } \\
(n=209)\end{array}$} & \multicolumn{2}{|c|}{$\begin{array}{c}\text { Boys } \\
(n=130)\end{array}$} & \multicolumn{2}{|c|}{$\begin{array}{c}\text { Girls } \\
(n=160)\end{array}$} & \multicolumn{2}{|c|}{$\begin{array}{c}\text { Boys } \\
(n=149)\end{array}$} & \multicolumn{2}{|c|}{$\begin{array}{c}\text { Girls } \\
(n=193)\end{array}$} & \multicolumn{2}{|c|}{$\begin{array}{c}\text { Boys } \\
(n=505)\end{array}$} & \multicolumn{2}{|c|}{$\begin{array}{c}\text { Girls } \\
(n=562)\end{array}$} \\
\hline & & $\mathrm{n}$ & $\%$ & $\mathrm{n}$ & $\%$ & $\mathrm{n}$ & $\%$ & $\mathrm{n}$ & $\%$ & $\mathrm{n}$ & $\%$ & $n$ & $\%$ & $\mathrm{n}$ & $\%$ & $n$ & $\%$ \\
\hline \multicolumn{18}{|c|}{ Sport for all } \\
\hline \multicolumn{2}{|c|}{ Do not undertake } & 11 & 4.9 & 13 & 6.2 & 6 & 4.6 & 4 & 2.5 & 3 & 2.0 & 6 & 3.1 & 20 & 4.0 & 26 & 2.6 \\
\hline \multirow{3}{*}{ Undertake* } & Regularly & 134 & 62.3 & 113 & $58.5^{b}$ & 76 & 61.3 & 78 & 50.0 & 92 & $63.0^{\mathrm{a}}$ & 82 & 43.9 & 302 & $62.3^{\mathrm{a}}$ & 273 & 50.9 \\
\hline & Periodically & 45 & 20.9 & 50 & 25.9 & 31 & 25.0 & 41 & 26.3 & 34 & 23.3 & 68 & $36.4^{\mathrm{a}, \mathrm{c}}$ & 110 & 22.7 & 159 & 29.7 \\
\hline & Sporadically & 36 & 16.7 & 30 & 15.5 & 17 & 13.7 & 37 & 23.7 & 20 & 13.7 & 37 & 19.8 & 73 & 15.1 & 104 & 19.4 \\
\hline \multicolumn{18}{|c|}{ Holidays } \\
\hline \multicolumn{2}{|c|}{ Physically active } & 82 & 36.3 & 74 & 35.4 & 56 & 43.1 & 64 & 40.0 & 60 & 40.5 & 82 & 42.5 & 198 & 39.3 & 220 & 39.1 \\
\hline \multicolumn{2}{|c|}{ Physically passive } & 144 & 63.7 & 135 & 64.6 & 74 & 56.9 & 96 & 60.0 & 88 & 59.5 & 111 & 57.5 & 306 & 60.7 & 342 & 60.9 \\
\hline
\end{tabular}

${ }^{*}$ percentages calculated on the basis of number of pupils undertaking sport for all; ** significantly different ( $\left.p \leq 0.05\right):{ }^{a}-$ boys vs. girls; ${ }^{b}-$ regularly vs. periodically and sporadically; ${ }^{c}$ - occasionally vs. regularly and periodically. 
Table 3. Determinants of physical activity of junior high school students $(n=1,067)$ and odds ratios $(O R)$ and the boundaries of $95 \%$ confidence interval $(95 \% \mathrm{Cl})$ of inactivity

\begin{tabular}{|c|c|c|c|c|c|c|c|}
\hline \multirow{3}{*}{ Variables } & \multicolumn{4}{|c|}{ Lower secondary school pupils } & \multirow{3}{*}{$p$} & \multirow{3}{*}{ OR } & \multirow{3}{*}{$95 \% \mathrm{Cl}$} \\
\hline & \multicolumn{2}{|c|}{ Active } & \multicolumn{2}{|c|}{ Inactive } & & & \\
\hline & $n$ & $\%$ & $\mathrm{n}$ & $\%$ & & & \\
\hline Sex & & & & & 0.026 & & \\
\hline Boys & 150 & 29.7 & 355 & 70.3 & & 0.73 & $0.56-0.96$ \\
\hline Girls & 133 & 23.7 & 429 & 76.3 & & 1 & \\
\hline Grade & & & & & NS & & \\
\hline I & 109 & 25.1 & 326 & 74.9 & & 1 & \\
\hline$\|$ & 81 & 27.9 & 209 & 72.1 & & 0.86 & $0.62-1.21$ \\
\hline III & 93 & 27.2 & 249 & 72.8 & & 0.90 & $0.65-1.24$ \\
\hline BMI & & & & & 0.036 & & \\
\hline Underweight & 100 & 29.9 & 234 & 70.1 & & 0.3 & $0.11-0.78$ \\
\hline Norm & 166 & 28.0 & 427 & 72.0 & & 0.33 & $0.13-0.85$ \\
\hline Overweight/obesity & 5 & 11.4 & 39 & 88.6 & & 1 & \\
\hline Place of residence & & & & & 0.041 & & \\
\hline Town & 163 & 29.2 & 396 & 70.8 & & 0.75 & $0.57-0.99$ \\
\hline Rural area & 120 & 23.6 & 388 & 76.4 & & 1 & \\
\hline Voivodeships & & & & & NS & & \\
\hline Cuiavian-Pomeranian & 182 & 25.1 & 542 & 74.9 & & 0.88 & $0.52-1.52$ \\
\hline Warmia-Masurian & 42 & 35.0 & 78 & 65.0 & & 0.55 & $0.29-1.04$ \\
\hline Greater Poland & 19 & 32.2 & 40 & 67.8 & & 0.63 & $0.30-1.32$ \\
\hline Łódź & 19 & 22.9 & 64 & 77.1 & & 1 & \\
\hline Masovian & 21 & 25.9 & 60 & 74.1 & & 0.85 & $0.42-1.73$ \\
\hline
\end{tabular}

Significant differences $(p \leq 0.05)$ between inactivity and activity; odds ratios $(O R)$ were computed with reference to the inactive.

Factors significantly differentiating respondents in this respect included their sex $\left(\mathrm{Chi}^{2}=4.96, \mathrm{df}=1\right.$; $\mathrm{p} \leq$ 0.05), $\mathrm{BMI}\left(\mathrm{Chi}^{2}=6.67, \mathrm{df}=2 ; \mathrm{p} \leq 0.05\right)$ and place of residence $\left(\mathrm{Chi}^{2}=4.19, \mathrm{df}=1 ; \mathrm{p} \leq 0.05\right)$ (Table 3). The majority of respondents were characterized by normal weight (61.1\%) or underweight (up $34.4 \%$ ). The existence of a correlation between the frequency of physical inactivity and sex of the respondents was found only among girls. Designated for the analyzed variables, the odds ratios indicate that the risk of inactivity increased by almost 1.4 times $(76.3 \%)$. A risk of a similar magnitude $(O R=0.75)$ was also noted in relation to all junior high school students living in the rural areas (76.4\%). On the other hand, the chance of being an active person increases more than 3-fold among junior high school students with normal BMI (28.0\%) and the underweight ones $(29.9 \%)$.

\section{Discussion}

The results of recent epidemiological and clinical studies have shown that lifestyle diseases commonly occur among people who take little physical activity or do not take it at all (Vuori, 2004). Unfortunately, this problem is becoming more common in case of children and adolescents (Dowda et al., 2001; Sterdt et al., 2014). According to the EU Physical Activity Guidelines (2008) the school children should undertake daily physical activity (in developmentally appropriate forms) at a moderate or intensive level for 60 minutes or longer (full dose can be cumulated in at least 10 -minute rounds). At the same time, the first criterion of physical activity is its regularity. 
In the community of researched junior high school students, on the whole, the declarations of participation in sport for all are very high (95.7\%). Higher than in the American youth population, where $77 \%$ undertake recreational activity in leisure time and 39\% - organized sports (Duke et al., 2003). Unfortunately, however, regularly only $56.3 \%$ of Polish junior high school students practice sport. The widely known phenomenon has been confirmed that if we ask about any physical activity at all - almost all respondents replied in an affirmative manner. If, however, the respondents are asked to describe in detail the frequency - the active fraction decreases drastically. In our case, it decreased by almost half. Given the above, it has to be assumed, following Wojtyła et al. (2011), that the Polish youth physical activity is limited largely to physical education classes; assuming at the same time that the examined junior high school students obligatorily attend these classes ( 3 hrs. weekly) and thus their physical activity (even in case of those who exercise regularly in their spare time) is too small to sustain health (not to mention proper development). This is not an isolated phenomenon. Researchers around the world are reporting that many young people do not apply the recommended dose of physical activity. For example, 3 out of 10 boys and 4 of 10 girls (aged 5-18 years) in the UK do not do it (Department of Health, 2003). Moderate efforts, lasting no less than 30 minutes at least five days a week, are taken by only $36 \%$ of the American and $35 \%$ of the Polish school children (Department of Health, 2003; Cabak, Woynarowska, 2004). It is not surprising that in Finland sport (4-5 times a week) is practiced by $13 \%$ of girls and $20 \%$ boys of school age. Quite surprising, though, is high level of physical activity of Lithuanian youth. According to Bergier, Bergier and Wojtyła (2012) it is achieved by $90.0 \%$ of boys and $71.9 \%$ of girls of school age. Perhaps such result is partly due to applying the long version of IPAQ in which all efforts of everyday life are analyzed. However, the earlier Polish studies (using the short version of the IPAQ among pupils in last year of lower secondary school and high school and the students in $1^{\text {st }}$ and $4^{\text {th }}$ years) reveal that a high level of physical activity applies to only $28.2 \%$ of young people (Biernat, Tomaszewski, 2013).

The above mentioned study - just like the previous one by Allender, Cowburn and Foster (2006) indicates even a downward trend in physical activity as pupils move to a higher grade. Payne, Townsend and Foster (2013) proved that along with the increasing pupils' age, their participation in active forms of recreation declines, particularly among girls. It is a very disturbing phenomenon. The more so that as Huk-Wieliczuk and Litwiniuk (2003) claim, in addition to reducing the level of physical activity, the range of forms of motor involvement becomes limited.

A non-gradual adverse change is noted between first graders (39.5\% inactive) and third graders (47.7\% inactive) - which confirms the hypothesis. It can obviously be explained by the fact that 3 rd graders devote more time to prepare for entrance exams for secondary schools. It is arguable, however, to say that education for recreational physical activity takes place at school stage (Kriemler et al., 2011). School education is expected to have far greater effect on physical culture of young people (both in terms of quantity and quality, both in the classroom and in their free time) (Lubowiecki-Vikuk, Podgórski, 2016). The interactions between school activities and sports education towards active leisure in later life are of virtuous circle nature. Unfortunately, Polish researchers pay attention to the low level of physiological knowledge of physical education teachers, the lack of sharing with pupils elementary knowledge of the impact of physical activity on the human body, the lack of interest in their own physical activity, not to mention promoting it among their pupils (Dębicki, Kuśnierz, 2003). They also show that, despite the introduction of the reform program, extracurricular and after-school physical activity is not at a satisfactory level, and young people possess too low level of knowledge about health, its maintenance and prevention (Dobbins et al., 2013). In European countries, not only schools but also families and peer groups are expected to have their share inn improving the lifestyle of the researched social group (Viner et al., 2012). It is all reflected in the behavior of the 
surveyed junior high school students (both during the school year and during holidays). It turns out that as many as $60.8 \%$ of the respondents prefer passive recreation, such as: watching TV programs, playing computer games, reading books etc. (Lubowiecki-Vikuk, Paczyńska-Jędrycka, 2010). Thus, taking into account pupils who regularly undertake sport for all during the school year and at the same time actively spend their holidays - physically active (all year round), they account for only $27 \%$. It seems that the way out of this difficult situation - apart from increasing the awareness of the need for a permanent physical activity - is a practical action, such as prevalence of organized forms (in the place of residence as well as and during trips). Research done by Lubowiecki-Vikuk and PaczyńskaJędrycka (2010) conclusively shows that over $90 \%$ of children and adolescents eagerly participate in organized sport activities at summer camps.

Statistical analysis indicated that the respondents' inactivity was conditioned by the majority of studied factors. Factors increasing the risk were high BMI, living in the countryside and female sex. As for girls, the risk of lack of movement was more than 1.4 times higher than among boys. Most researchers show girls as less active (Aibar et al., 2013; Hardman et al., 2013; Pindus et al., 2014). One should also remember that junior high school is a period of physiological maturation (in Poland, very frequently, the stereotypes of not taking part in physical education classes during menstruation are still prevalent). Much qualitative data (own observations, reactions of the respondents, the expressed emotions and so on) confirmed this state of affairs. This fact is of significant importance since increased recreational physical activity, especially in childhood and in case of adolescent reduces the risk of many diseases (Ruiz et al., 2011).

Living in rural areas also contributes to the prevalence of low level physical activity among junior high school students. The risk in this case is 1.4 times higher than among pupils living in urban areas. Scientific research conducted among children and adults living in rural areas reveal the existence of numerous obstacles to undertake physical activity (Salmon et al., 2013). In contrast, Wojtyła et al. (2011) indicate that the problem of inactivity relates to the inhabitants of towns and the countryside as well. Until recently, the residents of rural areas - because of the acute shortage of free time, commitment to work on the farm, aversion to unnecessary physical effort, limitations on the access to the equipment and sports facilities, resistance to new and alien cultural patterns - showed little interest in recreational activity. Currently, the differences in the use of free time between urban and rural population is becoming blurred (Ruiz et al., 2011; Salmon et al., 2013; Pindus et al., 2014). The state of sports infrastructure in rural areas is improving. The number of people with higher education is increasing, which inevitably leads to a change of attitudes of rural families to physical education (Salmon et al., 2013; LubowieckiVikuk, Biernat, 2015).

Another factor shaping the physical activity of junior high school students was BMI (Kantanista et al., 2015). Among students with a normal BMI the underweight ones, the risk of inactivity decreased over threefold. It would confirm Tremblay and Willms (2003) thesis that the lower BMI, the higher the activity. It does not, however, change the fact that being underweight can also be a factor increasing the risk of physical activity deficiency, which is the issue raised by Kantanista and Osiński (2014).

\section{Limitations}

Surveys were carried out on the basis of the declaration of junior high school students, which - despite a thorough explanation of the terminology used - could lead to an overestimation of physical activity. 


\section{References}

Aibar, A., Bois, J.E., Generelo, E., Zaragoza Casterad, J., \& Paillard, T. (2013). A cross-cultural study of adolescents' physical activity levels in France and Spain. European Journal of Sport Science, 13, 551-558. DOI: 10.1080/17461.391.2012.746733.

Allender, S., Cowburn, G., \& Foster, C. (2006). Understanding participation in sport and physical activity among children and adults: a review of qualitative studies. Health Education Research, 21, 826-835.

Bergier, B., Bergier, J., \& Wojtyła, A. (2012). Various aspects of physical activity among Lithuanian adolescents. Annals of Agricultural and Environmental Medicine, 19, 775-779.

Biernat, E., \& Tomaszewski, P. (2013). Tourist activity of young people as a factor contributing to their health and proper development. Annals of Agricultural and Environmental Medicine, 20, 524-529.

Cabak, A., \& Woynarowska, B. (2004). Physical activity of youths aged 11-15 years in year 2002 in Poland and in other countries. Physical Education and Sport, 48, 361-366.

Department of Health (2003). Health Survey for England 2002: The health of children and young people. London: Stationery Office.

Dębicki, D., \& Kuśnierz, C. (2003). Is physical education teacher the propagator of health style of life? Annales Universitatis Mariae Curie Skłodowska Sectio D Medicina, LVIIII, 256-261.

Dias, D.F., Loch, M.R., \& Ronque, E.R.V. (2015). Perceived barriers to leisure-time physical activity and associated factors in adolescents. Ciência \& Saúde Coletiva, 20 (11), 3339-3350. DOI: 10.1590/1413.812.320152011.005.92014.

Dobbins, M., Husson, H., DeCorby, K., \& LaRocca, R.L. (2013). School-based physical activity programs for promoting physical activity and fitness in children and adolescents aged 6 to 18. Cochrane Database of Systematic Reviews, 2, CD007651. DOI: 10.1002/14651858.CD007651.pub2.

Dowda, M., Ainsworth, B.E., Addy, C.L., Saunders, R., \& Riner, W. (2001). Environmental influences, physical activity, and weight status in 8 - to 16-year-olds. Archives of Pediatrics and Adolescent Medicine, 155, 711-717.

Duke, J., Huhman, M., \& Heitzler, C. (2003). Physical activity levels among children aged 9 to 13 years: United States, 2002. Morbidity and Mortality Weekly Report Surveillance Summaries, 52, 785-788.

EU Physical Activity Guidelines. (2008, March 14). Recommended Policy Actions in Support of Health-Enhancing Physical Activity. Approved by the EU Working Group "Sport \& Health" at its meeting, Sep 25, 2008, Confirmed by EU Member State Sport Ministers at their meeting in Biarritz, Nov 27-28, 2008, Oct 10 2008, Brussels. Retrieved from: http://www.ec.europa.eu/sport/ library/policy_documents/eu-physical-activity-guidelines-2008_en.pdf.

European Sports Charter. 1992. (2015, December 14). Retrieved from: http://www.ethicsandsport.com/public/uploads/files/The_ European_Sports_Charter\%5B1\%5D.pdf.

Hardman, C.M., Honda Barros, S.S., Siqueira de Souza Andrade, M.L., do Nascimento, J.V., Nahas, M.V., \& Gomes de Barros, M.V. (2013). Participation in physical education classes and indicators of attitudes toward physical activity in adolescents. Revista Brasileira de Educação Física e Esporte, 27, 623-631.

Huk-Wieliczuk, E., \& Litwiniuk, A. (2003). Out of school recreational sport activity as a healthy life style element? Annales Universitatis Mariae Curie Skłodowska Sectio D Medicina, LVIIII, 481-485.

Kantanista, A., \& Osiński, W. (2014). Underweight in 14 to 16 year-old girls and boys: prevalence and associations with physical activity and sedentary activities. Annals of Agricultural and Environmental Medicine, 21, 114-119.

Kantanista, A., Osiński, W., Borowiec, J., Tomczak, M., \& Król-Zielińska, M. (2015). Body image, BMI, and physical activity in girls and boys aged 14-16 years. Body Image, 15, 40-43. DOI: 10.1016/j.bodyim.2015.05.001.

Kriemler, S., Meyer, U., Martin, E., Van Sluijs, E.M.F., Andersen, L.B., \& Martin, B.W. (2011). Effect of school-based interventions on physical activity and fitness in children and adolescents: a review of reviews and systematic update. British Journal of Sports Medicine, 45, 923-930. DOI: 10.1136/bjsports-2011-090186.

Lee, I.M., Shiroma, E.J., Lobelo, F., Puska, P., Blair, S.N., \& Katzmarzyk, P.T. (2012). Effect of physical inactivity on major noncommunicable diseases worldwide: an analysis of burden of disease and life expectancy. Lancet, 380, 219-229. DOI: 10.1016/ S0140-6736(12)61031-9.

Lo, F.E., Tsai, F.C., Lee, M.B., Tsai, L.T., Lyu, S.Y., \& Yang, C.C. (2015). Contextual factors influencing leisure physical activity of urbanized indigenous adolescents. Journal of the Formosan Medical Association, 114 (11), 1082-1087. DOI: 10.1016/j.jfma.2014.03.014.

Lubowiecki-Vikuk, A., \& Biernat, E. (2015). Zorganizowane i niezorganizowane formy aktywności fizycznej młodzieży gimnazjalnej w czasie wolnym na tle czynników osobniczych i społeczno-środowiskowych. Problemy Higieny i Epidemiologii, 96 (2), $448-457$. 
Lubowiecki-Vikuk, A., \& Paczyńska-Jędrycka, M. (2010). Współczesne tendencje w rozwoju form rekreacyjnych i turystycznych. Poznań: Bogucki Wydawnictwo Naukowe.

Lubowiecki-Vikuk, A., \& Podgórski, Z. (2016). Tourist behaviour of junior high school students of the selected voivodeships in Poland: the socio-demographic context. Quaestiones Geographicae, 35 (1), 37-46. DOI: 10.1515/quageo-2016-0003.

Parvizi, S., \& Hamzehgardeshi, Z. (2014). Adolescents' view of health concept and its risk factors: a literature review. International Journal of Adolescent Medicine and Health, 26, 351-359. DOI: 10.1515/ijamh-2013-0311.

Payne, S., Townsend, N., \& Foster, C. (2013). The physical activity profile of active children in England. International Journal of Behavioral Nutrition and Physical Activity, 10, 136. DOI: 10.1186/1479-5868-10-136.

Pindus, D.M., Cumming, S.P., Sherar, L.B., Gammon, C., Coelho e Silva, M., \& Malina, R.M. (2014). Maturity-Associated Variation in Physical Activity and Health-Related Quality of Life in British Adolescent Girls: Moderating Effects of Peer Acceptance. International Journal of Behavioral Medicine, 21, 757-766.

Ruiz, J.R., Ortega, F.B., Martínez-Gómez, D., Labayen, I., Moreno, L.A., De Bourdeaudhuij, I., Sjöström, M. (2011). Objectively Measured Physical Activity and Sedentary Time in European Adolescents: The HELENA Study. American Journal of Epidemiology, 174, 173-184. DOI: 10.1093/aje/kwr068.

Salmon, J., Veitch, J., Abbott, G., ChinAPaw, M., Brug, J.J., teVelde, S.J., Ball, K. (2013). Are associations between the perceived home and neighborhood environment and children's physical activity and sedentary behaviour moderated by urban/rural location? Health \& Place, 24, 44-53. DOI: 10.1016/j.healthplace.2013.07.010.

Soos I., Biddle S., Boros-Balint I., Sandor I., Szabo P., Hamar P., Simonek, J. (2012). Prevalence of sedentary behaviour in young people in Romania and Slovakia. European Physical Education Review, 18, 19-46. DOI: 10.1177/1356336X11430659.

Soos I., Biddle S.J.H., Ling J., Hamar P., Sandor I., Boros-Balint I., Simonek, J. (2014). Physical activity, sedentary behaviour, use of electronic media, and snacking among youth: an international study. Kinesiology, 46 (2), 155-163.

Sterdt, E., Liersch, S., \& Walter, U. (2014). Correlates of physical activity of children and adolescents: A systematic review of reviews. Health Education Journal, 73, 72-89.

Trang, N.H., Hong, T.K., Dibley, M.J., \& Sibbritt, D.W. (2009). Factors associated with physical inactivity in adolescents in Ho Chi Minh City, Vietnam. Medicine and Science in Sports and Exercise, 41 (7), 1374-1383. DOI: 10.1249/MSS.0b013e31819c0dd3.

Tremblay, M., \& Willms, J. (2003). Is the Canadian childhood obesity epidemic related to physical inactivity? International Journal of Obesity, 27, 1100-1105.

Viner, R.M., Ozer, E.M., Denny, S., Marmot, M., Resnick, M., Fatusi, A., \& Currie, C. (2012). Adolescence and the social determinants of Heath. Lancet, 379, 1641-1652. DOI: 10.1016/S0140-6736(12)60149-4.

Vuori, I. (2004). Physical inactivity as a disease risk and health benefits of increased physical activity. In: P. Oja \& J. Borms (Eds.), Health enhancing physical activity (pp. 29-95). Meyer \& Meyer.

Wang, H., Fu, J., Lu, Q., Tao, F., \& Hao J. (2014). Physical activity, Body Mass Index and mental health in Chinese adolescents: a population based study. The Journal of Sports Medicine and Physical Fitness, 54, 518-525.

Wojtyła, A., Biliński, P., Bojar, I., \& Wojtyła, K. (2011) Physical activity among junior high school adolescents in Poland. Problemy Higieny i Epidemiologii, 92, 335-3.

Cite this anticle aS: Biernat, E., Lubowiecki-Vikuk, A. (2017). Socio-Demographic Determinants of Leisure Time Physical Inactivity of Adolescentsiln Aged 13-16. Central European Journal of Sport Sciences and Medicine, 17 (1), 41-50. DOI: 10.18276/cej.2017.1-05. 